\title{
The Synthesis of Unsymmetrical Urea from Substituted Phenethylamine and the Investigation of its Antibacterial, Anticancer, and Antioxidant Properties
}

\author{
Fatma Betül Özgeriş ${ }^{1}\left(\mathbb{D}\right.$, Fatma Necmiye Kaci ${ }^{2} \mathbb{D}$, Bünyamin Özgeriş ${ }^{3, *(\mathbb{D})}$, Arzu Görmez ${ }^{4, * \mathbb{C}}$ \\ 1 Department of Nutrition and Dietetics, Faculty of Health Science, Ataturk University, 25240 Erzurum, Turkey; \\ betul.ozgeris@atauni.edu.tr (F.B.O.); \\ 2 Department of Molecular Biology and Genetics, Faculty of Science, Erzurum Technical University, 25050 Erzurum, \\ Turkey; necmiye.kaci@erzurum.edu.tr (F.N.K.); \\ 3 Department of Basic Sciences, Faculty of Science, Erzurum Technical University, 25050 Erzurum, Turkey; \\ bunyamin.ozgeris@erzurum.edu.tr (B.O.); \\ 4 Department of Molecular Biology and Genetics, Faculty of Science, Erzurum Technical University, 25050 Erzurum, \\ Turkey; arzugormez@erzurum.edu.tr (A.G.); \\ * Correspondence: bunyamin.ozgeris@erzurum.edu.tr (B.Ö.); arzugormez@erzurum.edu.tr (A.G.);
}

Scopus Author ID 56897270700

Received: 21.09.2021; Revised: 20.10.2021; Accepted: 24.10.2021; Published: 21.11.2021

\begin{abstract}
There are numerous derivatives having urea scaffold in the literature, and these have many biological activities such as anticancer, antioxidant, antibacterial. Therefore, it aimed to synthesize urea derivatives containing substituted phenethylamine rings and investigate their biological properties such as anticancer, antimicrobial, and antioxidant. The antibacterial activity was carried out against four different bacterial strains (Escherichia coli ATCC 25922, Staphylococcus aureus ATCC 25923, Enterococcus faecalis ATCC 29212, and Pseudomonas aeruginosa ATCC 27853) by disc diffusion test. The synthesized compound was analyzed for their in vitro anticancer activity on SH-SY5Y (human neuroblastoma), HeLa (human cervical cancer), and A549 (non-small cell lung carcinoma) cell lines by using MTT, and LDH assays. The compound was inactive against all tested bacterial strains. The anticancer activity studies revealed that the unsymmetrical urea compound had remarkable activity against the tested cell lines, especially against the HeLa cell line with $50,61 \mu \mathrm{g} / \mathrm{ml} \mathrm{IC} \mathrm{I}_{50}$ value. The compound was also analyzed for its antioxidant capacity by DPPH, ABTS, and CUPRAC methods. According to the results, the compound showed good to moderate activity against standard antioxidants. Therefore, this compound may be considered an anticancer and antioxidant agent in treating cancer and other related diseases.
\end{abstract}

Keywords: unsymmetrical urea; phenethylamine; antibacterial activity; anticancer activity; antioxidant properties.

(C) 2021 by the authors. This article is an open-access article distributed under the terms and conditions of the Creative Commons Attribution (CC BY) license (https://creativecommons.org/licenses/by/4.0/).

\section{Introduction}

Phenethylamine is a natural monoamine alkaloid, which acts as a neurotransmitter in the human central nervous system [1]. It is also a trace amine and is found throughout the central nervous system. Trace amines play important roles in neurotransmission and neuromodulation. Determination of trace amines in the brain is very important to understand their role in neuropsychiatric disorders. Trace amines like phenethylamine have significant roles in a wide range of psychiatric and neurological disorders such as depression, 
schizophrenia, Parkinson's, epilepsy, attention deficit hyperactivity disorder, and Reye's syndrome [2].

Urea is an important functional group. Its derivatives have various applications in the agricultural field, medicinal chemistry, and chemical transformations [3]. Urea derivatives have a broad spectrum of biological activities such as anti-HIV, antibacterial, antiviral, analgesic, HDL elevating [4], and anti-Alzheimer [5]. There are many studies on the synthesis of urea derivatives in the literature, especially based on anticancer activity [6]. Many aromatic urea derivatives have been shown to have good anticancer activity [7]. For example, unsymmetrical urea compound $\mathbf{1}$ containing phenethylamine ring has been reported to have cytotoxicity against KB, MCF-7, NCI-H187, and Vero cell lines [8]. Symmetrical urea compound 2 has been reported to promote adipocyte differentiation in 3T3-L1 cells [9]. Another example is that unsymmetrical urea compound 3 has exhibited significant activity against the HT-29 cell line (Figure 1) [10].

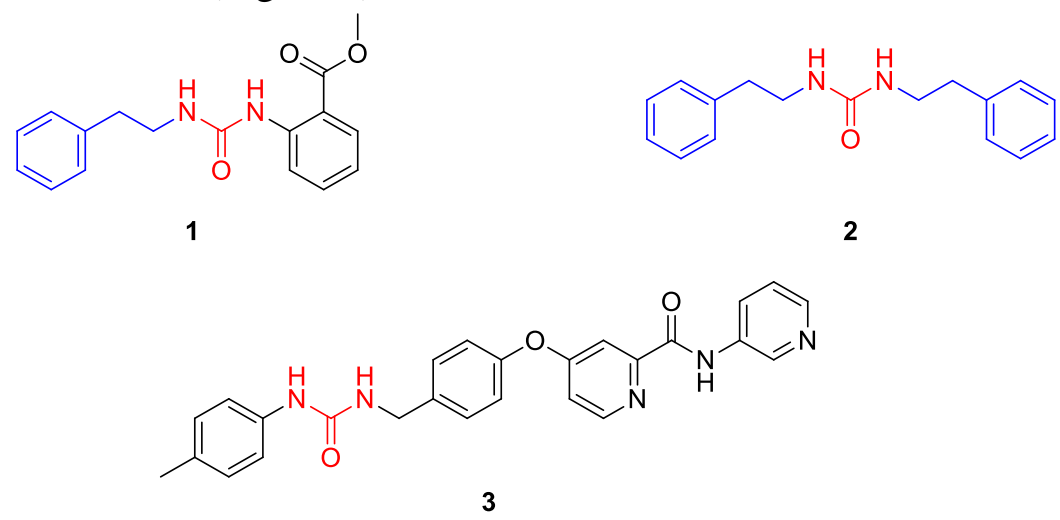

Figure 1. Some biologically active urea derivatives 1-3.

Lung [11] and cervical [12] cancers are the greatest harm to human health among the numerous forms of cancer. Chemotherapy has proven unsatisfactory in recent years due to multidrug-resistant tumors [13]. Cancer treatment, on the other hand, remains a substantial challenge for medicinal chemists.

Both the phenethylamine and urea moieties have important biological functions, as can be observed. As a result of the foregoing, the goal of this study was to synthesize an unsymmetrical phenethylamine urea derivative and examine its antibacterial, anticancer, and antioxidant activities.

\section{Materials and Methods}

\subsection{General methods.}

4-Methoxyphenethylamine (98\%), 3-Methoxyphenethylamine (97\%), 1,1'carbonyldiimidazole (CDI) (reagent grade), $\mathrm{CDCl}_{3}$ (99.8\%) were obtained from Sigma-Aldrich and were used without purification. The reactions were followed using thin-layer chromatography (TLC) by utilizing aluminum-backed Merck Silica-Gel 60 F254 plates. Preparative TLC was performed using Merck silica gel 60 HF254+366. The characterization of the organic product was performed using a $400 \mathrm{MHz}$ Bruker NMR instrument. The melting point was determined on the Electrothermal IA 9100 capillary melting point apparatus and is uncorrected. IR spectrum was obtained from solutions in $0.1 \mathrm{~mm}$ cells with a Perkin-Elmer spectrophotometer. Elemental analysis was performed on a Leco CHNS-932 apparatus. 
2.2. Synthesis procedure for 1-(3-methoxyphenethyl)-3-(4-methoxyphenethyl) urea (6).

4-Methoxyphenethylamine (5) $(0,75 \mathrm{~g}, 1 \mathrm{mmol})$ was taken in water at room temperature and stirred at $0^{\circ} \mathrm{C}$. CDI $(0,97 \mathrm{~g}, 1.2 \mathrm{mmol})$ was added to the reaction mixture at the same temperature. The reaction mixture was stirred at $0^{\circ} \mathrm{C}$ for 1 hour and then warmed up to room temperature. The reaction was monitored with TLC. After complete formation of carbonylimidazolide intermediate, 3-Methoxyphenethylamine $(0,90 \mathrm{~g}, 1.2 \mathrm{mmol})$ was added. The reaction mixture was stirred at room temperature for 4 hours and monitored by TLC. At the end of the reaction time, the mixture was filtered. The precipitate obtained was washed with cold water and dried. Recrystallization from EtOAc/Hexane afforded unsymmetrical urea compound 6 (1,10 g, 67\%). White solid. Mp 91-93 ${ }^{\circ} \mathrm{C}$. IR $\left(\mathrm{CH}_{2} \mathrm{Cl}_{2}, \mathrm{~cm}^{-1}\right): 3354,3320,3023$, 2930, 1615, 1568, 1503, 1245, 1036.

${ }^{1} \mathrm{H}$ NMR $\left(400 \mathrm{MHz}, \mathrm{CDCl}_{3}\right): \delta=7.18(\mathrm{dd}, \mathrm{J}=14.0,6.3 \mathrm{~Hz}, 1 \mathrm{H}, \mathrm{ArH}), 7.12-6.99(\mathrm{~m}$, 3H, ArH), $6.84-6.78$ (m, 2H, ArH), $6.77-6.69$ (m, 2H, ArH), 4.78 (br.s, 2H, NH), 3.79 (s, $\left.6 \mathrm{H}, \mathrm{OCH}_{3}\right), 3.34\left(\mathrm{~m}, 4 \mathrm{H}, \mathrm{CH}_{2}\right), 2.70\left(\mathrm{dt}, J=16.2,7.0 \mathrm{~Hz}, 4 \mathrm{H}, \mathrm{CH}_{2}\right) ;{ }^{13} \mathrm{C}$ NMR $(100 \mathrm{MHz}$, $\left.\mathrm{CDCl}_{3}\right): \delta=159.8(\mathrm{CO}), 158.3(\mathrm{C}), 158.2(\mathrm{C}), 140.9(\mathrm{C}), 131.2(\mathrm{C}), 129.7(2 \mathrm{CH}), 129.5(\mathrm{CH})$, $121.1(\mathrm{CH}), 114.5(\mathrm{CH}), 114.0(2 \mathrm{CH}), 111.7(\mathrm{CH}), 55.2\left(\mathrm{OCH}_{3}\right), 55.1\left(\mathrm{OCH}_{3}\right), 41.8\left(\mathrm{CH}_{2}\right)$, $41.5\left(\mathrm{CH}_{2}\right), 36.5\left(\mathrm{CH}_{2}\right), 35.5\left(\mathrm{CH}_{2}\right)$. Anal. Calcd for $\left(\mathrm{C}_{19} \mathrm{H}_{24} \mathrm{~N}_{2} \mathrm{O}_{3}\right): \mathrm{C}, 69.49 ; \mathrm{H}, 7.37 ; \mathrm{N}, 8.53$. Found: C, 69.46; H, 7.40; N, 8.55.

\subsection{Bioassay.}

\subsubsection{Culture of cells.}

All cell lines were purchased from ATCC (American Type Culture Collection, Manassas, VA, USA). The cells were grown and maintained in Dulbecco's Modified Eagle Medium / Nutrient Mixture F-12 (DMEM-F12) medium containing 10\% fetal bovine serum (FBS) and 1\% penicillin-streptomycin (Gibco, Life Technologies GmbH, Germany). Cells were cultured in a humidified atmosphere at $37^{\circ} \mathrm{C}$ in $5 \% \mathrm{CO}_{2}$. The medium was refreshed every 2 days.

\subsection{Measurement of cell growth by MTT assay.}

Antiproliferative effects of 1-(3-methoxyphenethyl)-3-(4-methoxyphenethyl) urea 6 on SH-SY5Y, HeLa, and A549 were determined by MTT cell proliferation assay. MTT (3-[4,5dimethylthiazol-2-yl]-2,5- diphenyltetrazolium bromide) is a yellow auxiliary agent that reduces formazan crystals in living cells. MTT was purchased from Sigma Chemical Company (St. Louis, Missouri, USA). $2 \times 10^{4}$ cells were inoculated in each well of 96- well plates. The cells were incubated in the absence or presence of 1-(3-methoxyphenethyl)-3-(4methoxyphenethyl) urea $6(3.125,6.25,12.5,25,50,100,200 \mu \mathrm{g} / \mathrm{ml})$ for $48 \mathrm{~h}$. After incubation periods, $20 \mu \mathrm{l}$ of MTT solution (MTT stock solution: $5 \mathrm{mg} / \mathrm{ml}$ in phosphate-buffered saline) was added to each well, and the cells were incubated at $37^{\circ} \mathrm{C}, 5 \% \mathrm{CO}_{2}$ containing incubator for 3 hours. Then, plates were centrifuged at $1800 \mathrm{rpm}$ for 10 minutes. The supernatant was removed, and $150 \mu \mathrm{LMSO}$ (Sigma-Aldrich ${ }^{\circledR}$, USA) was added to each well to dissolve the formazan crystals. Finally, the absorbance values were measured at $570 \mathrm{~nm}$ by a spectrophotometer [14]. The viability was determined as the percentage of absorbance of 1-(3methoxyphenethyl)-3-(4-methoxyphenethyl) urea 6 treated cultures compared with untreated control cultures. In the experiment used as a positive control, cells were treated with $1 \%$ Triton 
X-100 (Sigma-Aldrich @). Whereas used as a negative control, cells were studied without 1(3-methoxyphenethyl)-3-(4-methoxyphenethyl) urea 6 [15].

\section{5. $\mathrm{LDH}$ release assay.}

Cell membrane integrity is evaluated by LDH (lactate dehydrogenase) method. For this purpose, the level of cytoplasmic lactate dehydrogenase (LDH) released from dead or damaged cells is determined. This study applied LDH cytotoxicity assay kit (Cayman Chemical Company ${ }^{\circledR}$, Ann Arbor, MI, USA) according to the manufacturer's instructions for LDH assay application. The cells were seeded to 96 -well plates, and from 3.125 to $200 \mu \mathrm{g} / \mathrm{ml}$ of 1-(3methoxyphenethyl)-3-(4-methoxyphenethyl) urea 6 were applied to cell culture as triplicates for 48 hours. Then, $100 \mu \mathrm{L}$ supernatant was transferred to a fresh 96-well plate, and $100 \mu \mathrm{l}$ of the reaction mixture was added to the samples and incubated for $30 \mathrm{~min}$ at room temperature. Finally, a microplate reader was used to analyze the absorbance of the cultures at $490 \mathrm{~nm}$ [14].

\subsection{Antibacterial activity.}

The utilized test bacteria were obtained from the ATCC (American Type Culture Collection, Rockville, MD). Escherichia coli ATCC 25922, Staphylococcus aureus ATCC 25923, Enterococcus faecalis ATCC 29212, Pseudomonas aeruginosa ATCC 27853 were used for antibacterial activity. The disc diffusion method on Mueller Hinton Agar (MHA) was used to determine antibacterial activity $[16,17]$.

All bacterial strains prepared for MacFarland standardization (0.5), which is $1.5 \times 108 / \mathrm{ml}$ cell density, are inoculated in the Mueller-Hinton Broth. Then, $100 \mu \mathrm{l}$ bacterial suspension was inoculated in MHA plates. Empty sterilized disks were used to apply compound 6 (31.25-, 62.5-, 125-, 250-, 500- and $1000 \mu \mathrm{g} \mathrm{ml}^{-1}$ ). Tetracycline and streptomycin were used as the positive control. DMSO was used as a negative control. Then, these plates were incubated under suitable conditions, which was at $37^{\circ} \mathrm{C}$ for $24 \mathrm{~h}$. At the end of the incubation, antimicrobial activity was measured using the inhibition zone in $\mathrm{mm}$ against the tested strains. The experiments were repeated in triplicates [18].

\subsection{Antioxidant determination.}

The total radical scavenging capacity of the tested compounds was determined by the $\mathrm{DPPH}^{*}$ scavenging method as per the reported procedure and compared to that of BHT, $\beta$ Carotene, Trolox, and ascorbic acid [19]. The solution of $\mathrm{DPPH}^{\circ}$ was daily prepared, stored in a flask coated with aluminum foil, and kept in the dark at $4^{\circ} \mathrm{C}$. In brief, a fresh solution of $\mathrm{DPPH}^{*}(0.1 \mathrm{mM})$ was prepared in ethanol. Then, $1.5 \mathrm{~mL}$ of each novel urea compound 6 in ethanol has added an aliquot $(0.5 \mathrm{ml})$ of this solution $(6.25-200 \mu \mathrm{g} / \mathrm{ml})$. These mixtures were mixed vigorously and incubated in the dark for $30 \mathrm{~min}$. Finally, the absorbance value was recorded at $517 \mathrm{~nm}$ in a spectrophotometer [20].

$\mathrm{ABTS}^{\cdot+}$ scavenging method is based on the method's ability described by Re et al. [21]. The ABTS solution $(2 \mathrm{mM})$ in water with an oxidizing agent of potassium persulfate $(2.3 \mathrm{mM})$ yielded the ABTS cation radical $\left(\mathrm{ABTS}^{\cdot+}\right)$, which was soluble in both aqueous and organic solvents. It was diluted with phosphate buffer $(0.1 \mathrm{mM}, \mathrm{pH} 7.4)$ to adjust inquired absorbance $(0.700 \pm 0.025)$ at $734 \mathrm{~nm}$. Finally, the tested sample solution $(3 \mathrm{ml})$ at various concentrations $(6.25-200 \mu \mathrm{g} / \mathrm{ml})$ has interacted with $\operatorname{ABTS}^{\circ+}(1 \mathrm{ml})$, and the remaining absorbance was spectrophotometrically recorded at $734 \mathrm{~nm}$. 
The capability to scavenge the $\mathrm{DPPH}^{\circ}$ and $\mathrm{ABTS}^{\cdot+}$ radical were calculated using the following equation:

$$
\operatorname{RSE}(\%)=[1-\text { As } / \text { Ac })] \times 100
$$

where, RSE is radical scavenging effects, AC is the absorbance value of the control, and AS is the absorbance value of the sample [22,23].

The half-maximal scavenging concentration of the sample ( $\left.\mathrm{IC}_{50}\right)$ was determined from the graph plotted inhibition percentage against compound concentrations ( $\mu \mathrm{g} / \mathrm{ml})$ [24].

Cupric ions $\left(\mathrm{Cu}^{2+}\right)$ reducing power was used as the reducing ability method for compound 6. $\mathrm{Cu}^{2+}$ reducing capability was performed according to the reported method [25]. For this purpose, aliquots of $\mathrm{CuCl}_{2}$ solution $(0.25 \mathrm{ml}, 0.01 \mathrm{M})$, ethanolic neocuproine solution $\left(0.25 \mathrm{ml}, 7.5 \times 10^{-3} \mathrm{M}\right)$, and $\mathrm{NH}_{4} \mathrm{Ac}$ buffer solution $(0.25 \mathrm{ml}, 1 \mathrm{M})$ were transferred to a test tube, which contains compound 6 at different concentrations $(6.25-200 \mu \mathrm{g} / \mathrm{ml})$. Total volume was completed with distilled $\mathrm{H}_{2} \mathrm{O}$ to $2 \mathrm{~mL}$ and shaken. The absorbance of samples was recorded at $450 \mathrm{~nm}$ after $30 \mathrm{~min}$.

\subsection{Statistical analysis.}

Statistical analysis was performed using SPSS Statistics for Windows, statistical program SPSS software (version 20.0, SPSS, Chicago, IL, USA. Duncan's test was used to determine whether any treatment significantly differed from controls or each other. Statistical decisions were made with a significance level of 0.05 .

\section{Results and Discussion}

\subsection{Chemistry.}

There are various methods and reagents for the synthesis of symmetrical or unsymmetrical ureas in the literature. Oxidative carbonylation of amines [26], dialkyl-based exchange processes [27], phosgene, triphosgene, 1,1'-carbonylimidazole (CDI), chloroformates, isocyanates [28], and carbonylimidazolium salt [29] are some of these methods and reagents. There are some disadvantages associated with many of them, although these reagents have still been used extensively. Phosgene and triphosgene are not especially useful because of high toxicity and moisture sensitivity. CDI is moisture sensitive, but it reacts with amines to give $\mathrm{N}$-substituted carbonylimidazolide intermediate, converted to urea. Padiya has developed a new method for synthesizing ureas with CDI and concluded that an in-water imidazolecarbonylation reaction provides a highly efficient and general method for preparing ureas [30]. In this method, an anhydrous solvent and an inert atmosphere do not require. Our previous study also synthesized substituted phenethylamine-based urea and investigated their anticancer activity [31]. We thus decided to apply this method for the synthesis of unsymmetrical urea. For this purpose, 4-methoxyphenethylamine 4 was reacted with CDI and obtained $\mathrm{N}$-substituted imidazolide intermediate. Then, this intermediate was reacted with 3 methoxyphenethylamine $\mathbf{5}$ in situ. As a result of this procedure, unsymmetrical urea compound 6 was synthesized. The synthetic route to the title compound is shown in Figure 2.

The chemical structures of the synthesized compound were elucidated with ${ }^{1} \mathrm{H}$ NMR, ${ }^{13} \mathrm{C} \mathrm{NMR}$, IR, and elemental analysis. In the ${ }^{1} \mathrm{H}$ NMR spectrum of compound $\mathbf{6}$, the characteristic signals due to the $-\mathrm{HN}(\mathrm{CO}) \mathrm{NH}$ - and two $-\mathrm{OCH}_{3}$ protons on the unsymmetrical urea appeared at $4.78 \mathrm{ppm}$ as broad singlet and $3.79 \mathrm{ppm}$ as a singlet, respectively. In the ${ }^{13} \mathrm{C}$ NMR spectrum of compound 6, $-\mathrm{CO}$ and two $-\mathrm{OCH}_{3}$ signals appeared at 159.8, 55.2, and 55.1 
ppm, respectively. In addition to these signals, four $-\mathrm{CH}_{2}$ signals belonging to the phenethylamine ring appeared at between 41.8 and $35.5 \mathrm{ppm}$. Furthermore, the total number of carbon signals were appeared as 17 because of the symmetry of the methoxy group attached to carbon at the para position of the left phenethylamine ring. These spectral data confirm the structure of 1-(3-methoxyphenethyl)-3-(4-methoxyphenethyl) urea $6 .{ }^{1} \mathrm{H}$ and ${ }^{13} \mathrm{C}$ NMR spectra are given in Figure 3.

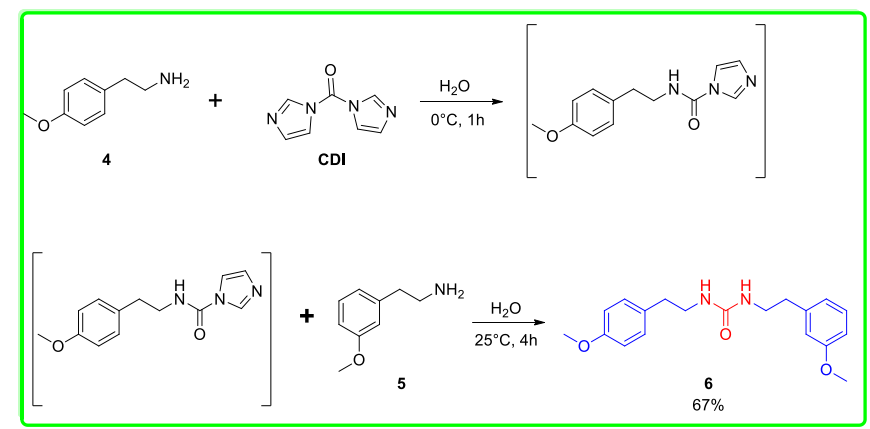

Figure 2. The synthetic route to the title compound 6.
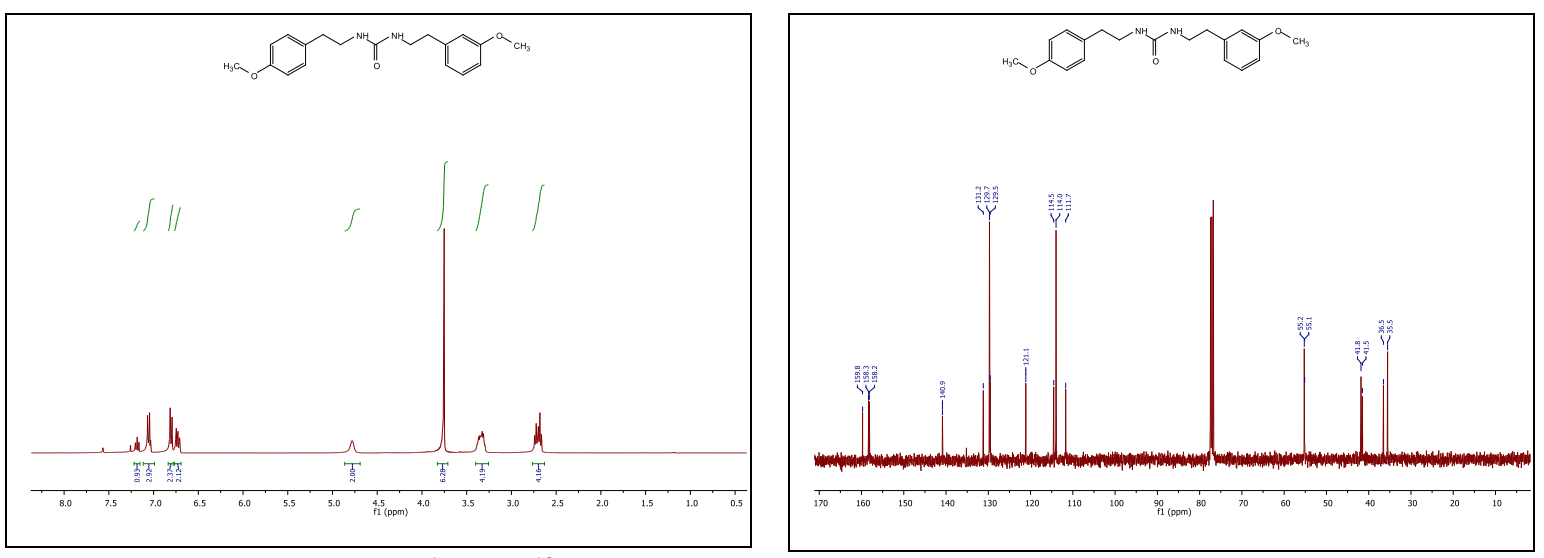

Figure 3. ${ }^{1} \mathrm{H}$ and ${ }^{13} \mathrm{C}$ NMR spectra of unsymmetrical urea $6\left(\mathrm{CDCl}_{3}\right)$.

\subsection{Bioassay.}

In biological assays, the synthesized compound had no antimicrobial activity against $E$. coli ATCC 25922, S. aureus ATCC 25923, E. faecalis ATCC 29212, and P. aeruginosa ATCC 27853.

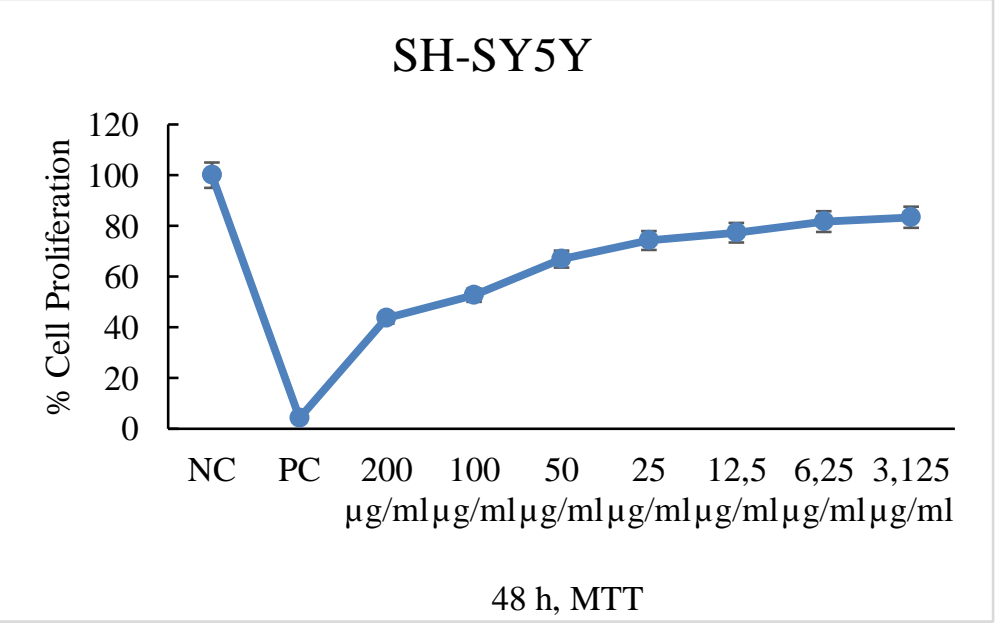

Figure 4. Cytotoxic effects of 1-(3-methoxyphenethyl)-3-(4-methoxyphenethyl) urea 6 on SH-SY5Y cells $(\mathrm{p}<0.05)$ (Error bars represents standard deviations (SD), $\mathrm{p}<0.05$ was considered as significant). 
The synthesized compound $\mathbf{6}$ was screened for cytotoxic activity against SH-SY5Y, HeLa, and A549 cell lines.

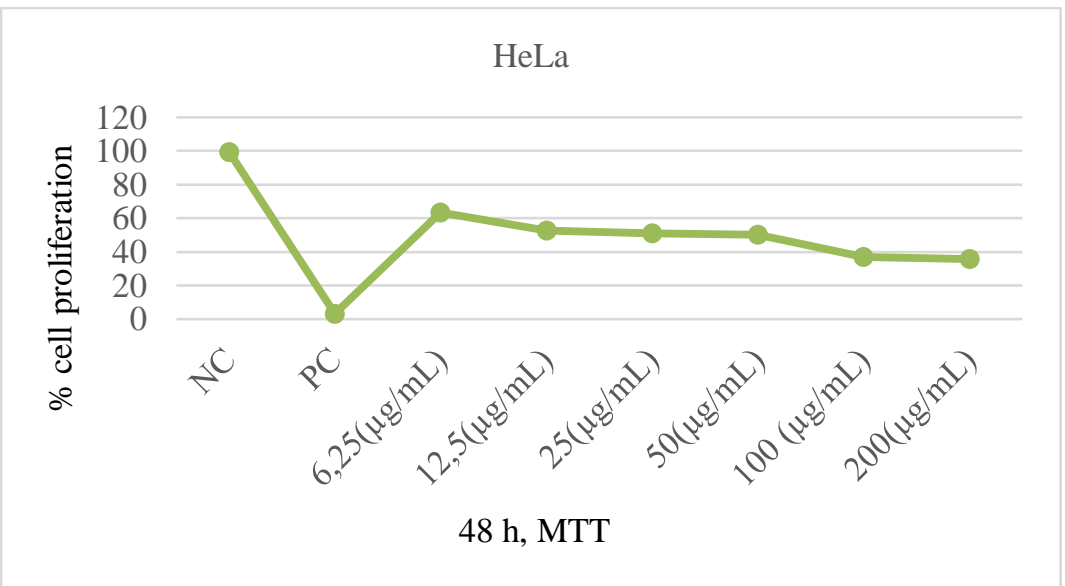

Figure 5. Cytotoxic effects of 1-(3-methoxyphenethyl)-3-(4-methoxyphenethyl) urea 6 on HeLa cells ( $\mathrm{p}<0.05)$

(Error bars represents standard deviations (SD), $\mathrm{p}<0.05$ was considered as significant).

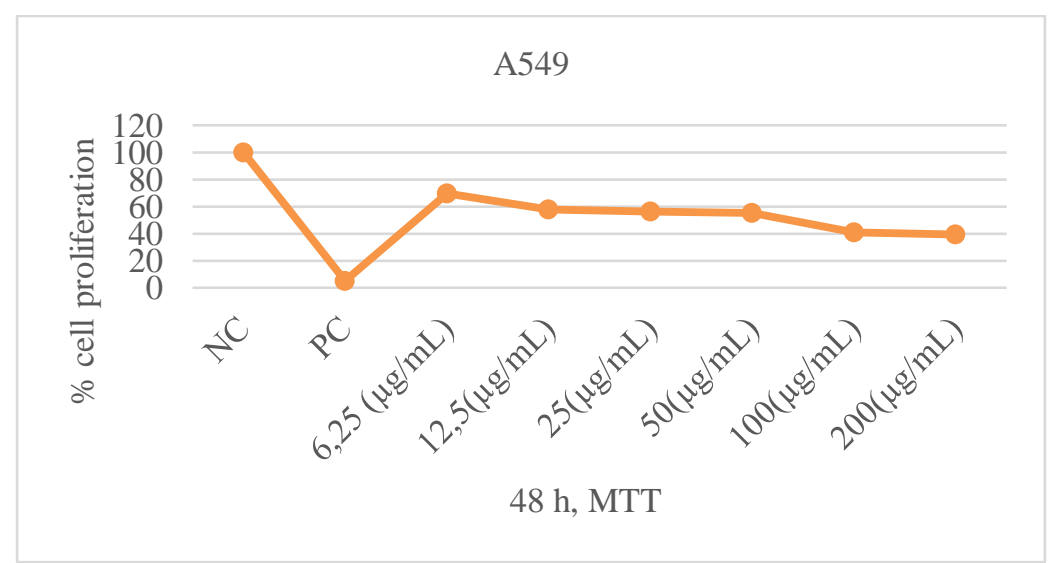

Figure 6. Cytotoxic effects of 1-(3-methoxyphenethyl)-3-(4-methoxyphenethyl) urea 6 on A549 cells ( $\mathrm{p}<0.05)$ (Error bars represents standard deviations (SD), $\mathrm{p}<0.05$ was considered as significant).

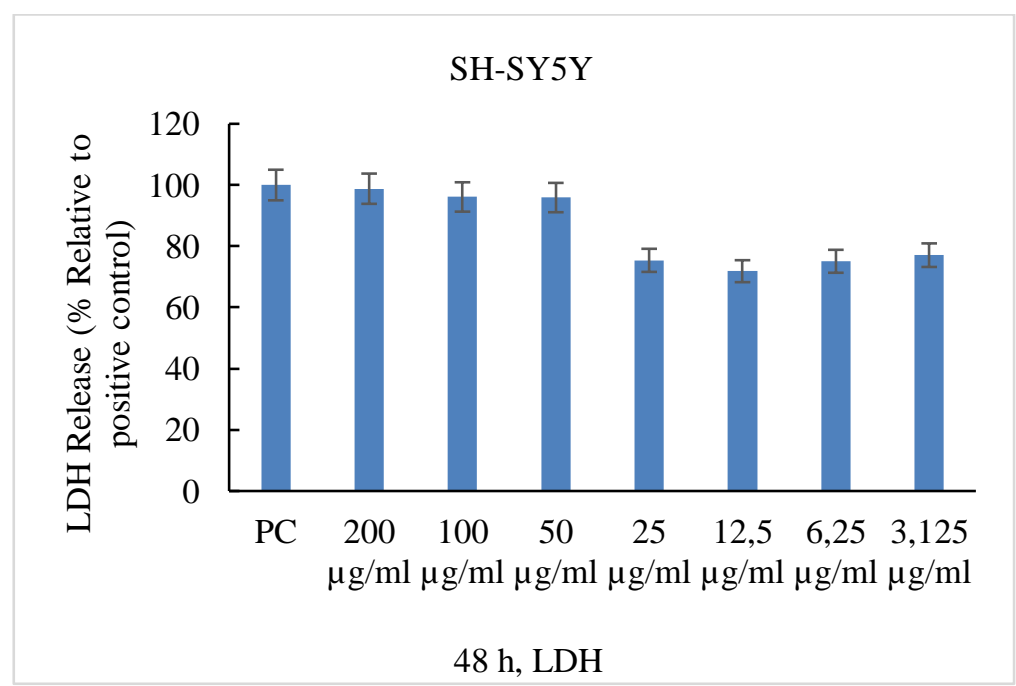

Figure 7. The lactate dehydrogenase (LDH) cytotoxicity results of 1-(3-methoxyphenethyl)-3-(4methoxyphenethyl) urea 6 on SH-SY5Y cells. Cell line was treated with 1-(3-methoxyphenethyl)-3-(4methoxyphenethyl) urea 6 in a range of concentrations from 3.125 to $200 \mu \mathrm{g} / \mathrm{ml}$ based on the results of MTT.

Triton X-100 (1\%) solution was used as a positive control.

All cells were treated with increasing concentrations of 1-(3-methoxyphenethyl)-3-(4methoxyphenethyl) urea $\mathbf{6}$ for 48 hours, and MTT cell proliferation assay was carried out to 
determine the antiproliferative effects of the agent on these cells. The cells were exposed to 1(3-methoxyphenethyl)-3-(4-methoxyphenethyl) urea 6 from 3.125 to $200 \mu \mathrm{g} / \mathrm{ml}$. The results showed that there were dose-dependent decreases in cell proliferation as compared to untreated controls $(\mathrm{p}<0.05)$.

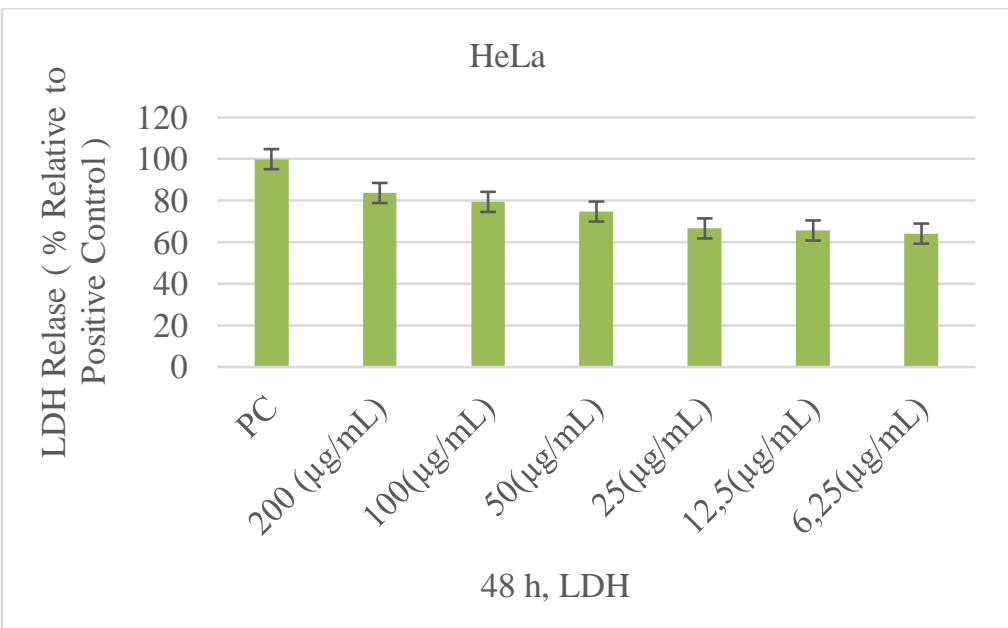

Figure 8. The lactate dehydrogenase (LDH) cytotoxicity results of 1-(3-methoxyphenethyl)-3-(4methoxyphenethyl) urea 6 on HeLa cells. Cell line was treated with 1-(3-methoxyphenethyl)-3-(4methoxyphenethyl) urea 6 in a range of concentrations from 3.125 to $200 \mu \mathrm{g} / \mathrm{ml}$ based on the results of MTT.

Triton X-100 (1\%) solution was used as a positive control.

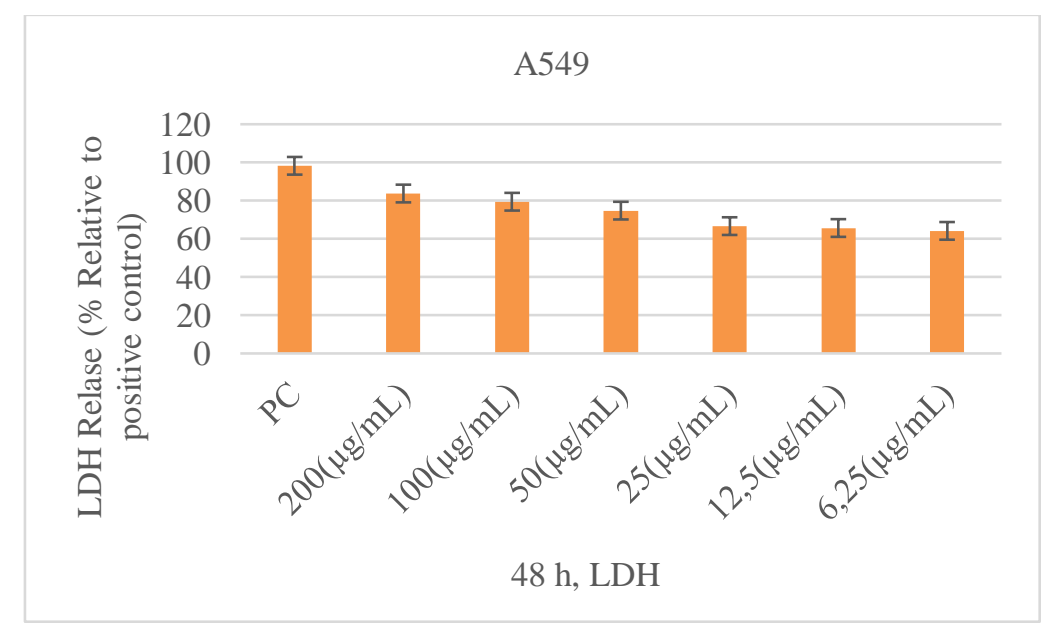

Figure 9. The lactate dehydrogenase (LDH) cytotoxicity results of 1-(3-methoxyphenethyl)-3-(4methoxyphenethyl) urea 6 on HeLa cells. Cell line was treated with 1-(3-methoxyphenethyl)-3-(4methoxyphenethyl) urea 6 in a range of concentrations from 3.125 to $200 \mu \mathrm{g} / \mathrm{ml}$ based on the results of MTT.

Triton X-100 (1\%) solution was used as a positive control.

As a result, $\mathrm{IC}_{50}$ concentration of 1-(3-methoxyphenethyl)-3-(4-methoxyphenethyl) urea 6 on SH-SY5Y, HeLa, and A549 cells was calculated from cell proliferation plots and found to be $104 \mu \mathrm{g} / \mathrm{ml}, 50,61 \mu \mathrm{g} / \mathrm{ml}$, and $72,33 \mu \mathrm{g} / \mathrm{ml}$, respectively (Figure 4-6).

In order to confirm cytotoxic effects of 1-(3-methoxyphenethyl)-3-(4methoxyphenethyl) urea 6 on SH-SY5Y, HeLa, and A549 cells were performed LDH release assay (Figure 7-9). Similar to MTT, LDH assay also gave similar results on SH-SY5Y, HeLa, and A549 cells.

Compounds having CS, $\mathrm{CO}$, and $\mathrm{NH}$ groups have been shown to exhibit antibacterial activities, particularly against gram-negative bacteria [32], due to their ability to produce antibacterial activity by interacting with the carboxyl and phosphate groups on the bacterial surface [33]. Especially, it was reported that in the compounds the replacement of sulfur with 
oxygen in the urea, the presence of electron-withdrawing group on the aromatic ring are much more active in terms of antibacterial activity [34-36]. In parallel with these results, we demonstrated that substituted phenethylamine-based thiourea derivatives showed antibacterial activity [37]. Based upon these results, probably, our compound did not show any antibacterial activity against all tested bacteria because of the urea group in our structure. Therefore, it will be necessary to optimize the synthesized compound with different groups for antibacterial effect.

Looking at the cancer studies of the urea derivatives in the literature, similar to our results, Banti and co-workers indicated that urea derivatives have a strong antiproliferative effect against breast (MCF-7) and cervix (HeLa) carcinoma cell lines [38]. Mohamed and coworkers indicated that newly synthesized urea compounds showed significant cytotoxic activity against liver (HePG2) and MCF-7 cell lines [39]. According to a recent study, most EWG (electron-withdrawing groups), such as the fluoro group, have more activity than EDG (electron-donating groups), such as the methyl and methoxy groups [40]. Despite the presence of a methyl (EDG) group in the para position of the phenethylamine ring in our molecule, it has a significant level of action against the HeLa cell line. Notably, we demonstrated that substituted phenethylamine-based urea derivatives showed highly strong anticancer activity against HeLa and A549 cell lines [41]. Despite investigating the cytotoxic activities of these urea compounds, the newly synthesized urea compound in the present study has not been previously examined against cancer cells.

Cytostatic drugs have shown their antitumor effects by disrupting specific cell structures or metabolic pathways of cancer cells. Radiotherapy and some chemotherapeutics have caused cellular death by producing free radicals, while antioxidants neutralize free radicals and free radical-mediated oxidative reactions $[42,43]$. To prevent cell damage, the levels of reactive oxygen species must be maintained at all times. When this balance cannot be maintained, the body activates the antioxidant defense system [44]. In this study, BHT, $\beta$ carotene, ascorbic acid, and Trolox were used as standard antioxidants.

When looking at the antioxidant results, our newly synthesized compound showed moderate activity compared to BHT, while less active than other standard antioxidants on the DPPH. Unlike the DPPH method, our compound demonstrated strong activity on the ABTS method compared to standard antioxidants, except ascorbic acid. In addition to these, our compound showed that moderate antioxidant activity compared to $\beta$-carotene on the Cuprac method.

Table 1. $\mathrm{IC}_{50}$ values of compound $\mathbf{6}$ on cancer cell lines and DPPH, ABTS, CUPRAC values of compound 6. $(\mathrm{p}<0.05)$.

$\mathrm{IC}_{50}(\mu \mathrm{M})$

$\lambda_{450} *$

\begin{tabular}{|c|c|c|c|c|c|c|c|c|c|}
\hline \multirow[b]{2}{*}{ Compound } & \multicolumn{2}{|c|}{ HeLa } & \multicolumn{2}{|c|}{ A549 } & \multicolumn{2}{|c|}{ SH-SY 5Y } & \multirow[t]{2}{*}{ DPPH } & \multirow[t]{2}{*}{ ABTS } & \multirow[t]{2}{*}{ CUPRAC } \\
\hline & MTT & LDH & MTT & LDH & MTT & LDH & & & \\
\hline $\begin{array}{l}0 \\
6\end{array}$ & 50,61 & 46,65 & 72,33 & 73,06 & 104 & 102 & 98,65 & 48,98 & $0.093 \pm 0.001$ \\
\hline Trolox & - & - & - & - & - & - & 96,85 & 58,89 & $0.173 \pm 0.002$ \\
\hline BHT & - & - & - & - & - & - & 105,97 & 86,29 & $0.151 \pm 0.001$ \\
\hline Ascorbic acid & - & - & - & - & - & - & 67,31 & 35,32 & $0.960 \pm 0.002$ \\
\hline$\beta$-carotene & - & - & - & - & - & - & 68,87 & 81,53 & $0.087 \pm 0.001$ \\
\hline
\end{tabular}

Cells were treated with concentrations ranging from 6.25 to $200 \mu \mathrm{M}$ for $48 \mathrm{~h}$. 
Notably, urea compounds containing methoxy or halogen have improved antioxidant activity, according to a recent study [45]. Our product has two methoxy groups on the phenethylamine ring. Therefore, our product showed good to moderate antioxidant activity.

As a result, the synthesized compound $\mathbf{6}$ has remarkable anticancer activity on SHSY5Y, HeLa, and A549 cells, especially against the HeLa cell line. Therefore, this new compound may be considered an anticancer and antioxidant agent in treating cancer and other related diseases.

\section{Conclusions}

Starting from substituted phenethylamine together with CDI, we synthesized unsymmetrical urea compound $\mathbf{6}$. The synthetic compound was investigated for anticancer, antibacterial, and antioxidant properties. The synthesized compound did not show any antibacterial activity against all tested bacteria. Further studies on the development of new urea compounds with effective groups may increase the application of the unsymmetrical urea compound $\mathbf{6}$ as an antibacterial agent. On the other hand, this compound significantly reduced the growth of neuroblastoma, HeLa, and A549 cancer cells, especially against the HeLa cell line. The unsymmetrical urea compound $\mathbf{6}$ was also investigated for its antioxidant capacity by DPPH, ABTS, and CUPRAC methods. According to our results, this compound showed strong to moderate activity compared to standard antioxidants. Therefore, it may be considered an anticancer and antioxidant agent in treating cancer and other related diseases. However, it will be aimed at improving the more active urea compounds based upon these experiments' results.

\section{Funding}

This research received no external funding.

\section{Acknowledgments}

This research was partially supported by Erzurum Technical University (Scientific Research Project, 2019/15). We are greatly indebted to Erzurum Technical University for their financial support and research conditions.

\section{Conflicts of Interest}

The authors declare no conflict of interest.

\section{References}

1. Sabelli, H.C.; Mosnaim, A.D.; Vazquez, A.J.; Giardina, W.J.; Borison, R.L.; Pedemonte, W.A. Biochemical plasticity of synaptic transmission: a critical review of Dale's Principle. Biol. Psychiatry 1976, 11, 481-524.

2. Khan, H.A.; Ullah, Q.; Ahmad, A.; Alhomida, A.S.; Al Rokayan, S.H.; Farooqui, T.; Farooqui, A.A. Chapter 2 - Methods of Trace Amine Analysis in Mammalian Brain. In Trace Amines and Neurological Disorders; Academic Press: San Diego 2016, 11-26.

3. Sivan, S.K.; Vangala, R.; Manga, V. Microwave assisted synthesis, molecular docking and HIV-1 gp120 CD4 binding inhibition studies of symmetrical N, N'-disubstituted urea/thiourea. Chem. Sci. Trans. 2014, 3, 1418-1426, 1419, https://doi.org/10.7598/cst2014.890.

4. Pochampally, J.; Valeru, A.; Macha, R.; Kishorekumar, A.; Tigulla, P.; Gandu, B.; Gangagnirao, A. Design, efficient new synthesis, evaluation of antimicrobial activity and molecular modeling studies of novel aryl substituted urea derivatives. Pharma Chem. 2014, 6, 269-282, 214.

5. Gok, N.; Akincioglu, A.; Binici, E.E.; Akincioglu, H.; Kilinc, N.; Goksu, S. Synthesis of novel sulfonamides with anti-Alzheimer and antioxidant capacities. Arch. Pharm. (Weinheim) 2021, 354, https://doi.org/10.1002/ardp.202000496. 
6. Nagalakshmamma, V.; Venkataswamy, M.; Pasala, C.; Maheswari, A.U.; Raju, K.T.; Nagaraju, C.; Chalapathi, P.V. A study on MAPK/ERK and CDK2-Cyclin-E signal switch "on and off" in cell proliferation by bis urea derivatives of 1, 4-Diisocyanatobenzene. Bioorg. Chem. 2021, 112, https://doi.org/10.1016/j.bioorg.2021.104940.

7. Huan-Qiu, L.; Peng-Cheng, L.; Tao Yan and Hai-Liang, Z. Urea Derivatives as Anticancer Agents. $\begin{array}{llllll}\text { Anticancer Agents } & \text { in }\end{array}$ https://doi.org/http://dx.doi.org/10.2174/1871520610909040471.

8. Boonlarppradab, C.; Suriyachadkun, C.; Supothina, S.; Laksanacharoen, P. Amethysione and amethysamide, new metabolites from Streptosporangium amethystogenes BCC 27081. J. Antibiot. 2016, 69, 459-463, https://doi.org/10.1038/ja.2015.128.

9. Chai, S.S.; Cha, B.Y.; Kagami, I.; Lee, Y.S.; Sasaki, H.; Suenaga, K.; Teruya, T.; Yonezawa, T.; Nagai, K.; Woo, J.T. N,N '-diphenethylurea isolated from Okinawan ascidian Didemnum molle enhances adipocyte differentiation in 3T3-L1 cells. J. Antibiot. 2011, 64, 277-280, https://doi.org/10.1038/ja.2010.168.

10. Lu, C.S.; K, T.; Y, L.; B, J.; DL, Y.; C, M.; XG, C.; Huang, H.H. Synthesis and in vitro antitumor activities of novel benzyl urea analogues of sorafenib. Acta Pharm. Sin. 2013, 48, 709-717.

11. Sun, H.Y.; Yin, M.C.; Hao, D.Q.; Shen, Y.X. Anti-Cancer Activity of Catechin against A549 Lung Carcinoma Cells by Induction of Cyclin Kinase Inhibitor p21 and Suppression of Cyclin E1 and P-AKT. Appl. Sci. 2020, 10, https://doi.org/10.3390/app10062065.

12. Gomaa, S.E.; Friedersdorf, M.; El Enshasy, H.A.; Abou-Donia, M.B. In vitro Comparative Study for Antiproliferative Activity of Some Plant Extracts, Fam. Apiaceae, on Human Cervical (HeLa) Cancer Cell Line. Indones. J. Pharm. 2020, 31, 108-115, https://doi.org/10.14499/indonesianjpharm31iss2pp108.

13. Toolabi, M.; Moghimi, S.; Bakhshaiesh, T.O.; Salarinejad, S.; Aghcheli, A.; Hasanvand, Z.; Nazeri, E.; Khalaj, A.; Esmaeili, R.; Foroumadi, A. 6-Cinnamoyl-4-arylaminothienopyrimidines as highly potent cytotoxic agents: Design, synthesis and structure-activity relationship studies. Eur. J. Med. Chem. 2020, 185, https://doi.org/10.1016/j.ejmech.2019.111786.

14. Chen, D.; Zhou, X.; Chen, X.; Huang, L.; Xi, X.; Ma, C.; Zhou, M.A.-O.; Wang, L.A.-O.; Chen, T.A.-O. Evaluating the Bioactivity of a Novel Antimicrobial and Anticancer Peptide, Dermaseptin-PS4(Der-PS4), from the Skin Secretion of Phyllomedusa sauvagii. Molecules 2019, 24, 2974, https://doi.org/10.3390/molecules24162974.

15. Sahin, I.; Ozgeris, F.B.; Kose, M.; Bakan, E.; Tumer, F. Synthesis, Characterization, and Antioxidant and Anticancer Activity of 1,4-Disubstituted 1,2,3-triazoles. J. Mol. Struct. 2021, 1232, https://doi.org/10.1016/j.molstruc.2021.130042.

16. Digafie, Z.; Melaku, Y.; Belay, Z.; Eswaramoorthy, R. Synthesis, Antibacterial, Antioxidant, and Molecular Modeling Studies of Novel 2,3 '-Biquinoline -4-Carboxylic Acid and Quinoline-3-Carbaldehyde Analogs. J. Chem. 2021, 2021, https://doi.org/10.1155/2021/9939506.

17. Babamale, H.F.; Sangeetha, T.; Tan, J.S.; Yam, W. Synthesis and characterization of azobenzene derivatives and azobenzene-imidazolium conjugates with selective antimicrobial potential. J. Mol. Struct. 2021, 1232, https://doi.org/10.1016/j.molstruc.2021.130049.

18. Buzon-Duran, L.; Capita, R.; Alonso-Calleja, C. Antibiotic susceptibility of methicillin-resistant staphylococci (MRS) of food origin: A comparison of agar disc diffusion method and a commercially available miniaturized test. Food microbiol. 2018, 72, 220-224.

19. Erdogan, M.; Kose, L.P.; Essiz, S.; Gulcin, I. Synthesis and biological evaluation of some 1-naphthol derivatives as antioxidants, acetylcholinesterase, and carbonic anhydrase inhibitors. Arch. Pharm. (Weinheim) 2021, 354, https://doi.org/10.1002/ardp.202100113.

20. Artunc, T.; Menzek, A.; Taslimi, P.; Gulcin, I.; Kazaz, C.; Sahin, E. Synthesis and antioxidant activities of phenol derivatives from 1,6-bis (dimethoxyphenyl)hexane-1,6-dione. Bioorg. Chem. 2020, 100, https://doi.org/10.1016/j.bioorg.2020.103884.

21. Re, R.; Pellegrini, N.; Proteggente, A.; Pannala, A.; Yang, M.; Rice-Evans, C. Antioxidant activity applying an improved ABTS radical cation decolorization assay. Free Radic. Biol. Med. 1999, 26, 1231-1237, https://doi.org/https://doi.org/10.1016/S0891-5849(98)00315-3.

22. Gülçin, İ.; Mshvildadze, V.; Gepdiremen, A.; Elias, R. Screening of antiradical and antioxidant activity of monodesmosides and crude extract from Leontice smirnowii tuber. Phytomedicine 2006, 13, 343-351, https://doi.org/https://doi.org/10.1016/j.phymed.2005.03.009.

23. Buldurun, K.; Turan, N.; Bursal, E.; Mantarci, A.; Turkan, F.; Taslimi, P.; Gulcin, I. Synthesis, spectroscopic properties, crystal structures, antioxidant activities and enzyme inhibition determination of $\mathrm{Co}$ (II) and $\mathrm{Fe}$ (II) complexes of Schiff base. Res. Chem. Intermed. 2020, 46, 283-297, https://doi.org/10.1007/s11164-01903949-3.

24. Aksu, K.; Ozgeris, B.; Taslimi, P.; Naderi, A.; Gulcin, I.; Goksu, S. Antioxidant Activity, Acetylcholinesterase, and Carbonic Anhydrase Inhibitory Properties of Novel Ureas Derived from Phenethylamines. Arch. Pharm. (Weinheim) 2016, 349, 944-954, https://doi.org/10.1002/ardp.201600183.

25. Oztaskin, N.; Kaya, R.; Maras, A.; Sahin, E.; Gulcin, I.; Goksu, S. Synthesis and characterization of novel bromophenols: Determination of their anticholinergic, antidiabetic and antioxidant activities. Bioorg. Chem. 2019, 87, 91-102, https://doi.org/10.1016/j.bioorg.2019.03.010. 
26. Diaz, D.J.; Darko, A.K.; McElwee-White, L. Transition metal-catalyzed oxidative carbonylation of amines to ureas. Eur. J. Org. Chem. 2007, 2007, 4453-4465, https://doi.org/10.1002/ejoe.200700148.

27. Tundo, P.; Selva, M. The chemistry of dimethyl carbonate. Acc. Chem. Res. 2002, 35, 706-716, https://doi.org/10.1021/ar010076f.

28. McMorris, T.C.; Chimmani, R.; Alisala, K.; Staake, M.D.; Banda, G.; Kelner, M.J. Structure-Activity Studies of Urea, Carbamate, and Sulfonamide Derivatives of Acylfulvene. J. Med. Chem. 2010, 53, 1109-1116, https://doi.org/10.1021/jm901384s.

29. Grzyb, J.A.; Shen, M.; Yoshina-Ishii, C.; Chi, W.; Brown, R.S.; Batey, R.A. Carbamoylimidazolium and thiocarbamoylimidazolium salts: novel reagents for the synthesis of ureas, thioureas, carbamates, thiocarbamates and amides. Tetrahedron 2005, 61, 7153-7175, https://doi.org/10.1016/j.tet.2005.05.056.

30. Padiya, K.J.; Gavade, S.; Kardile, B.; Tiwari, M.; Bajare, S.; Mane, M.; Gaware, V.; Varghese, S.; Harel, D.; Kurhade, S. Unprecedented "In Water" Imidazole Carbonylation: Paradigm Shift for Preparation of Urea and Carbamate. Org. Lett. 2012, 14, 2814-2817, https://doi.org/10.1021/ol301009d.

31. Ozgeris, B. Synthesis of potentially biologically active novel phenolic derivatives of unsymmetrical ureas from substituted phenethylamines. Monatsh. Chem. 2020, 151, 1851-1857, https://doi.org/10.1007/s00706020-02709-z.

32. Zhong, Z.; Xing, R.; Liu, S.; Wang, L.; Cai, S.; Li, P. Synthesis of acyl thiourea derivatives of chitosan and their antimicrobial activities in vitro. Carbohydr. Res. 2008, 343, 566-570, https://doi.org/https://doi.org/10.1016/j.carres.2007.11.024.

33. Ngaini, Z.; Arif, M.A.M.; Hussain, H.; Mei, E.S.; Tang, D.; Kamaluddin, D.H.A. Synthesis and antibacterial activity of acetoxybenzoyl thioureas with aryl and amino acid side chains. Phosphorus, Sulfur, Silicon Relat. Elem. 2012, 187, 1-7, https://doi.org/10.1080/10426507.2011.562398.

34. Chikhalia, K.H.; Patel, M.J. Design, synthesis and evaluation of some 1,3,5-triazinyl urea and thiourea derivatives as antimicrobial agents. J. Enzyme Inhib. Med. Chem. 2009, 24, 960-966, https://doi.org/10.1080/14756360802560966.

35. Kiranmai, M. Synthesis, Antimicrobial Activity and Docking Studies of Novel Urea and Thiourea Derivatives. IOSR J. Pharm. Biol. Sci. 2016, 11, 10-16, https://doi.org/10.9790/3008-1106031016.

36. Pasdar, H.; Hedayati Saghavaz, B.; Foroughifar, N.; Davallo, M. Synthesis, Characterization and Antibacterial Activity of Novel 1,3-Diethyl-1,3-bis(4-nitrophenyl)urea and Its Metal(II) Complexes. Molecules 2017, 22, 2125.

37. Özgeriş, B. Synthesis of Substituted Phenethylamine-Based Thioureas and Their Antimicrobial and Antioxidant Properties. Russ. J. Org. Chem. 2021, 57, 422-429, https://doi.org/10.1134/S1070428021030143.

38. Banti, C.N.; Poyraz, M.; Sainis, I.; Sari, M.; Rossos, G.; Kourkoumelis, N.; Hadjikakou, S.K. The periodic table of urea derivative: small molecules of zinc(II) and nickel(II) of diverse antimicrobial and antiproliferative applications. Mol. Divers. 2020, 24, 31-43, https://doi.org/10.1007/s11030-018-09909-0.

39. Mohamed, A.T.A.; Abou-Elregal, M.K.; Youssef, A.S.A.; Hemdan, M.M.; Samir, S.S.; Abou-Elmagd, W.S.I. Synthesis and antitumor activity evaluation of some thienopyrimidine derivatives. Synth. Commun. 2020, 50, 399-411, https://doi.org/10.1080/00397911.2019.1697822.

40. Liew, S.K.; Malagobadan, S.; Arshad, N.M.; Nagoor, N.H. A Review of the Structure-Activity Relationship of Natural and Synthetic Antimetastatic Compounds. Biomolecules 2020, 10, 138, https://doi.org/10.3390/biom10010138.

41. Ozgeris, F.B.; Ozgeris, B. Synthesis, characterization, and biological evaluations of substituted phenethylamine-based urea as anticancer and antioxidant agents. Monatsh. Chem. https://doi.org/10.1007/s00706-021-02830-7.

42. Weijl, N.I.; Cleton Fj Fau - Osanto, S. Free radicals and antioxidants in chemotherapy-induced toxicity. Cancer Treat. Rev. 1997, 23, 209-240.

43. Crohns, M.; Liippo, K.; Erhola, M.; Kankaanranta, H.; Moilanen, E.; Alho, H.; Kellokumpu-Lehtinen, P. Concurrent decline of several antioxidants and markers of oxidative stress during combination chemotherapy for small cell lung cancer. Clin. Biochem. 2009, 42, 1236-1245, https://doi.org/10.1016/j.clinbiochem.2009.05.003.

44. Pham-Huy, L.A.; He, H.; Pham-Huy, C. Free radicals, antioxidants in disease and health. Int. J. Biomed.l Sci. 2008, 4, 89-96.

45. Pavan Kumar, H.; Kumara, H.K.; Suhas, R.; Channe Gowda, D. Multitarget-directed therapeutics: (Urea/thiourea)2 derivatives of diverse heterocyclic-Lys conjugates. Arch. Pharm. (Weinheim) 2021, n/a, e2000468, https://doi.org/10.1002/ardp.202000468. 